\title{
Proceeding
}

Supplementary Issue: Spring Conferences of Sports Science. International Conference on Psychology of Education Sciences \& Lifestyle.

\section{Designing a pattern for the privatization of sports places with a data-based approach}

\author{
SHERMIN RAHMATI, MOZAFAR YEKTAYAR , MOZHGAN KHODAMORADPOOR, KUMARS AHMADIE \\ Islamic Azad University, Sananda, Islamic Republic of Iran
}

\begin{abstract}
This study was done to present a pattern for the development of a sports places privatization using a databased approach and by developed approach and in a qualitative form. All managers and experts related to the privatization of sport places constituted the statistical population of the study. Due to the qualitative research, totally 16 people were selected as statistical sample using snowball sampling technique. The data collection tool was the interview, which was conducted in Integers interviews until the theoretical saturation stage. Interview data were analysed through 3 stages of open, pivotal and selective coding. categories including causal conditions, contextual conditions, action strategies, and the developing consequences of sports places privatization program were extracted using open coding; Then, in the axial coding stage, the link between these categories was determined as follows in the form of coding pattern: causal conditions (structural factors, necessity of privatization, economic causes); contextual conditions (internal, political, and manpower resources, laws and prescriptions, economic, social, and cultural status, news coverage); action strategies (managerial, legal, privatization structure, cultural and social proceedings); and the consequences (economic development, manpower development, sport development, social development). Following, in the coding stage too, are described the components of coding pattern and finally, are formulated the research fiat statements. According to the results of present study, sports places privatization requires the creation of a transparent and appropriate platform in order to managers could privatizing the places in a proper competition.
\end{abstract}

Keywords: Pattern; Privatization; Sports places, Data-based.

\section{Cite this article as:}

Rahmati, S., Yektayar, M., Khodamoradpoor, M., \& Ahmadie, K. (2020). Designing a pattern for the privatization of sports places with a data-based approach. Journal of Human Sport and Exercise, 15(3proc), S944-S957. doi:https://doi.org/10.14198/ihse.2020.15.Proc3.46

Corresponding author. Islamic Azad University, Sananda, Islamic Republic of Iran.

E-mail: myektayar@gmail.com

Supplementary Issue: Spring Conferences of Sports Science. International Conference on Psychology of Education Sciences and Lifestyle.

JOURNAL OF HUMAN SPORT \& EXERCISE ISSN 1988-5202

(c) Faculty of Education. University of Alicante

doi:10.14198/jhse.2020.15.Proc3.46

S944 $2020 \mid$ Proc3 | VOLUME 15

(c) 2020 University of Alicante 


\section{INTRODUCTION}

Fictitious privatization is the process by which the tasks and facilities of the governmental sector are transferred to the private sector at every level; but privatization in the true concept refers to cultural diffusion in all levels of society that the legislator system, the judiciary and the executive and all people of a country believe that the issues of the people must be left to the people, that is, people have to perform their community-related duties and responsibilities without government intervention, and no institution and power can prevent them from fulfilling their responsibilities. Privatization does not just mean transferring state property to the nongovernmental sector Of course, this process can always be reversible by the government at any time. If the whole economic system of society is based on the will of the people, thereby giving the people the right of own and possession the factors of production, property, product, and the like, real and successful privatization has been achieved. Although the theoretical concept of privatization is not enough clear, in experimental researches, privatization is a governmental effort to reduce the demotivation existing in the efficiency of government organizes. and this is done by placing them in the private market motivations (Rahimi Boroujerdi, 2006).

The environment of government and non-profit organizations has become increasingly changed and agitated in recent years. Organizations must therefore transform their findings and perceptions into compatibly strategies to adjust to their changing environments and ultimately provide the appropriate and rational framework for adapting and implementing their strategies with reasoning and thinking. For this purpose, strategic planning approaches developed in the private sector can help private organizations that have a proper treatment to environments that have undergone tremendous changes and help them operate in a more efficient method (Ghanbari Firouzabadi, 2009). Privatization is one of the most important components of modern government management and has agrees and dissenters who each make their own arguments in this field; however, privatization as a policy has been accepted and implemented in the whole political and economic system of Iran; However, the malfunctioning and barriers of privatization performance have reduced its effectiveness and efficiency in solving the country's problems (Pour Ahmadi et al., 2018).

Many countries have paid special attention to the concept of privatization in the last 2 decades and implemented its performance mechanisms in order to use as a viable solution to rationalize the economic structure, reduce government financial burden, increase efficiency and productivity (Mosll Nejad et al., 2014). Due to the current economic changes in the sports field, it is clear that the current situation should change and special attention should be paid to privatization. One of the aspects of privatization in sport is sports places privatization, because by implementing this policy, governments are faced with lower budget deficits, quality increases, costs reduces (Eissens, 1994) and efficiency increases (Lindholm, 2005); but there are always positive and negative environmental factors that influence the privatization process, which are considered as internal and external environmental factors. In this new full of complexity and change world, organizations and governments are forced to change their plans more than ever due to the environmental conditions surrounding them; because the speed of change in today's environment is greater than performance of long-term plans (Mehrbanfar, 2016).

Privatization is broadly defined as a set of measures that will increase the efficiency of the state apparatus and reduce the focus of the state bureaucracy. In other words, privatization is the process that defines and develops private sector strategies. These strategies are done by removing the administrative and legal barriers to doing business in the private sector. In the broader concept, privatization is a process to limit the government executive powers and reducing direct government involvement in the economy (Taheri, 2005). 
The privatization program should be supported by top government officials to overcome the resistance and laziness created by the administrative system and self-interest. The program should be run by politicallyminded pragmatics as well as those who have access to technical expertise and skills globally, not by those who benefit from the status quo. The government must ensure that investors do not endanger their interests by using political influence. Confronting the privatization program with administrative opposition and political resistance is inevitable, as privatization will change the state apparatus. Placing a privatization task force near the centre of government power can eliminate administrative disagreement and control political issues well (Welch \& Fermound, 2010).

The successful implementation of the privatization policy by various governments has made the privatization as a key pillar of governmental policy consolidated in all subsequent governments. For example, in 1984 through the mid-1990s, many British state-owned companies were privatized, and the economy continued to grow during these years (Parker, 2013). The results of Amiri et al.'s (2013) research showed that the main barriers to sport privatization from the perspective of academic experts are as follows: managerial, culturalsocial, political-legal and economic barriers respectively and from the viewpoint of executives' management, barriers are, cultural - social, economic and political - legal, respectively. based on the perspective of executives, the most important managerial, cultural, social, economic and political-legal barriers to sport privatization in the country include indirect government competition with the private sector, managers' resistance to reduction government incumbency due to their dependence on the governmental sector, lack of investment security in the country, and The government's use of sport as a political tool.

The research results of Salimi et al. (2012) showed that economic factor have the first rank and executive, managerial, legal and social aspects have other rank. Nasseh (2013) also found that financial, educational, structural, managerial problems, and in addition, violations of customer rights significantly affected the privatization process; Therefore, it is important to adopt a well-structured strategy and build an effective organization that takes care of sports development issues and the proper application of privatization policies. Thus, the development of sport requires similar studies to estimate the extents to make the goals of the private course are achieved and the necessary modifications.

For this regard and in order to implementation of the policies of Article 44 of the Constitution and the continuation of economic, social and cultural development programs, privatization has been taken into consideration, as part of the goals set by economic transformation programs, the transfer of government activities to the private sector is being pursued to some extent, and the country's sports sector has been subject to these approvals and the privatization of sports venues as a sport infrastructure of the country has a special place. Given that popular supports and investment in the private sector are less valued as sports financial resources in Iran, and based on the results of the above-mentioned research on the insufficient private sector investment in field of sports places privatization and the likelihood of damages such as the giving the sports places to the private sector and the possibility of private sector loss and rejection of this investment Researchers are trying to present the potential for a win-win interchange between the country's sports framework and the private sector by analysing the underlying factors of developing a sports places privatization program and providing the necessary indicators.

\section{RESEARCH METHODOLOGY}

Given that this research seeks to analyse the underlying factors of the development of the sports places privatization program based on the votes and opinions of experienced elites and professors and enhances existing knowledge about the subject of present research is developmental and due to research results are 
applicable in order to the strategic management of the field concerned, they are application. The research methodology was done based on a qualitative research approach. In fact, qualitative researches that have an exploratory nature are used in cases where there is a concern about how phenomena occur and how they relate to one another, not in order to measure the relationship between variables. Since this research was intended to be a new and qualitative study, data-based method and qualitative analysis were used to achieve the research objectives.

The statistical population consisted of all experts in the field of privatization, including university professors (with books or research in the field of privatization) and managers of privatization-related organizations in the Ministry of Sport and Youth and the Privatization Organization. Since the study is qualitative, snowball sampling was used and in-depth interviews were conducted with them. Upon completion of the interview, each of the interviewees was asked to introduce the other privatization experts to the researcher; the sampling continued until the research team concluded that the new information was the same as the previous iteration and there is no other new conceptual information that needs to a new code or expanding the existing codes, or the study has reached "theoretical saturation" in other words. The opinions of 16 elite individuals were collected during the semi-structured interview in this study to reach the theoretical saturation level and the extracted files were analysed at various stages.

The present study aimed to increase the internal validity by providing feedback to the interviewees and placing them on the research path so as not to affect their responses. In the meantime, after each interview, the resulting pattern was presented up to that stage and if the interviewee had any suggestions for the template, discussed about that. This was done after the interview so that the interview was free of any assumptions and orientations.

Since the stability component discuss about the repeatability of the research findings and in the qualitative studies of the researcher, the interpretation of the subject under investigation does not require the creation of a traditional concept of reliability; therefore, in discussing the reliability of the research, how data collection, coding, concept extraction and categories selection should be demonstrated. Since the coding process was performed after each interview, coding results were presented to the interviewees to ensure accuracy. Also, the model obtained to that stage was presented to individuals to submit, after each interview, if they want to make changes or modifications, and then be reviewed and applied. Also, after each interview, the model obtained to that stage was presented to individuals to submit a change or amendment they want, and then the comments are reviewed and applied. In addition, in order to increase the certainty in the quality and accuracy of coding performed in this study, an attempt was made to evaluate the coding performed. In this study, the kappa coefficient of agreement between two coders was used to obtain reliability. The kappa coefficient was obtained 0.735 , which rejects the assumption of independence of the extracted codes and confirms their dependence on each other. Therefore, it can be said that coding was sufficiently reliable. Interviews were conducted with experts and experts to collect data and answer questions. Interviews continued until the theoretical saturation stage. Interviews were conducted using open and semi-open interviews. After collecting the data for qualitative analysis of the interviews using the basic theory, the files extracted from the interview were analysed and various analysis steps were performed to answer the questions.

\section{RESEARCH FINDINGS}

The descriptive findings of the study indicated that the samples in the qualitative phase were 15 males and 1 female, all had research or executive background in the subject, and were faculty members of universities 
and higher education centres; and 15 of the interviewees had a Ph. D or were PhD student and 1 person had a master's degree.

Table 1. Axial coding results level 2 of causal conditions

\begin{tabular}{|l|l|l|l|}
\hline Concepts & $\begin{array}{l}\text { Substructure } \\
\text { (Categories) }\end{array}$ & $\begin{array}{l}\text { The main } \\
\text { structure }\end{array}$ & Row \\
\hline Shrinking the government & Structure & $\begin{array}{l}\text { Causal } \\
\text { Conditions }\end{array}$ & 1 \\
\hline $\begin{array}{l}\text { Consider the long-term benefits of the sports places } \\
\text { privatization and added-value for community }\end{array}$ & & & 2 \\
\hline Reduction of government responsibility & & 3 \\
\hline $\begin{array}{l}\text { Lack of government inefficiency in private sector } \\
\text { productivity }\end{array}$ & $\begin{array}{l}\text { Necessity of } \\
\text { privatization }\end{array}$ & & 4 \\
\hline $\begin{array}{l}\text { The wide scope of the sports industry in the country and } \\
\text { the government's inability to implement sports places } \\
\text { privatization }\end{array}$ & & & 5 \\
\hline $\begin{array}{l}\text { Higher effectiveness by implementing sports places } \\
\text { privatization }\end{array}$ & & & 6 \\
\hline Economic conditions prevailing in society & & & 7 \\
\hline $\begin{array}{l}\text { The necessity of funding providing for the administrating of } \\
\text { governmental sports places }\end{array}$ & & & 8 \\
\hline Reducing the governmental budgets & & & 9 \\
\hline Proper use of limited government resources & & 10 \\
\hline
\end{tabular}

3 categories and 10 concepts are categorized into causal conditions, which are the structural factors, the need for privatization, and the economic factors that influence the pivotal phenomenon.

Table 2. Pivotal coding results of level 2 contextual conditions.

\begin{tabular}{|l|l|l|l|}
\hline Concepts & $\begin{array}{l}\text { Sub-structures } \\
\text { (categories) }\end{array}$ & $\begin{array}{l}\text { Main } \\
\text { structure }\end{array}$ & Row \\
\hline $\begin{array}{l}\text { High financial investing in the sports industry than in other } \\
\text { fields }\end{array}$ & $\begin{array}{l}\text { Internal } \\
\text { Recourses }\end{array}$ & $\begin{array}{l}\text { Contextual } \\
\text { Conditions }\end{array}$ & 1 \\
\hline Inadequate facilities provided by the government & & & 2 \\
\hline People's unwillingness to costing on sports & & & 3 \\
\hline $\begin{array}{l}\text { Lack of adequate financial power of the private sector in order } \\
\text { to enter the sports industry }\end{array}$ & & 4 \\
\hline $\begin{array}{l}\text { The high cost of using sports facilities in the private sector of } \\
\text { sports facilities }\end{array}$ & & & 5 \\
\hline $\begin{array}{l}\text { The low utilization rate of public places compared to the } \\
\text { private sector }\end{array}$ & & & 6 \\
\hline Unrealistic pricing & & & 7 \\
\hline Boycotts and inflation in the country & & 8 \\
\hline Political Appointment of Managers and Profit Rentals & & & 9 \\
\hline Security look at the assignment of sports places & & & 10 \\
\hline Political instability in the country & & & 11 \\
\hline
\end{tabular}




\begin{tabular}{|c|c|c|}
\hline $\begin{array}{l}\text { Political oversight and prevention of sports places } \\
\text { privatization }\end{array}$ & & 12 \\
\hline International restrictions on foreign investor entry & & 13 \\
\hline $\begin{array}{l}\text { Preference for political considerations rather than technical } \\
\text { considerations }\end{array}$ & & 14 \\
\hline Change in governments and change in policy & & 15 \\
\hline Managers' distrust of private sector managers & Manpower & 16 \\
\hline Not being a specialist in sports management & & 17 \\
\hline Employing empowered political leaders & & 18 \\
\hline Managers' resistance to change & & 19 \\
\hline Deploying two-business managers and reducing performance & & 20 \\
\hline Government managers' instability in decision making & & 21 \\
\hline $\begin{array}{l}\text { Acquaintance managers with private sector management } \\
\text { skills }\end{array}$ & & 22 \\
\hline $\begin{array}{l}\text { Low level of information literacy of managers in the private } \\
\text { sector }\end{array}$ & & 23 \\
\hline Managers jealous of competitors' progress & & 24 \\
\hline $\begin{array}{l}\text { Feeling the fear of government executives about shrinking the } \\
\text { organization and losing power }\end{array}$ & & 25 \\
\hline $\begin{array}{l}\text { Lack of government' cooperation and support for sports } \\
\text { places privatization }\end{array}$ & $\begin{array}{l}\text { Laws and } \\
\text { Prescriptions }\end{array}$ & 26 \\
\hline Lack of a long-term strategy in sports places privatization & & 27 \\
\hline Short-term assignment contracts & & 28 \\
\hline $\begin{array}{l}\text { Transparency or lack of transparency in the implementation of } \\
\text { sports places privatization }\end{array}$ & & 29 \\
\hline $\begin{array}{l}\text { Parallel and concurrent involvement of the Physical Education } \\
\text { Organization and other government agencies }\end{array}$ & & 30 \\
\hline Lack of proper pricing for private club services & & 31 \\
\hline $\begin{array}{l}\text { Strict laws of various state institutions in the administration of } \\
\text { private sports venues }\end{array}$ & & 32 \\
\hline Government ownership and unwillingness to lose power & & 33 \\
\hline Extra and encumbrance rules & & 34 \\
\hline $\begin{array}{l}\text { Lack of successful privatization patterns in other fields of the } \\
\text { country }\end{array}$ & & 35 \\
\hline Private sector dependency on government & & 36 \\
\hline Non-enforcement of upstream laws & & 37 \\
\hline $\begin{array}{l}\text { The upstream-downstream attitude of the government to } \\
\text { sports places privatization }\end{array}$ & & 38 \\
\hline Guaranteeing foreign investors & & 39 \\
\hline Proper and fair pricing of private sector sports facilities & & 40 \\
\hline $\begin{array}{l}\text { The existence of a trustee organization for planning and } \\
\text { policing in the private sector of sports facilities }\end{array}$ & & 41 \\
\hline $\begin{array}{l}\text { Coordination of private sport programs with the country's } \\
\text { grand and strategic plans }\end{array}$ & & 42 \\
\hline Allow free entry into and exhaust from competitive market & & 43 \\
\hline Unfair contracts in sports places privatization & & 44 \\
\hline
\end{tabular}




\begin{tabular}{|c|c|c|}
\hline $\begin{array}{l}\text { Government's failure to enforce sports places privatization } \\
\text { policy }\end{array}$ & & 45 \\
\hline Corruption in the country's administrative system & & 46 \\
\hline The taste performance of the rules at the down-stream levels & & 47 \\
\hline Facilitate the legal licensing of assignments & & 48 \\
\hline Employment laws and labour force & & 49 \\
\hline $\begin{array}{l}\text { Provision of legal framework for transfer to the private sector } \\
\text { of sports facilities }\end{array}$ & & 50 \\
\hline $\begin{array}{l}\text { Uncertain areas of implementation of sports places } \\
\text { privatization }\end{array}$ & & 51 \\
\hline $\begin{array}{l}\text { Implementing similar to government sectors instead of } \\
\text { privatization }\end{array}$ & & 52 \\
\hline $\begin{array}{l}\text { Lack of incentive for domestic and foreign investors in private } \\
\text { places }\end{array}$ & Economic status & 53 \\
\hline Creating an investment market for sports places privatization & & 54 \\
\hline Allocate government subsidies to enter the private sector & & 55 \\
\hline $\begin{array}{l}\text { Competition of the government and the private sector in } \\
\text { providing services and earning profits }\end{array}$ & & 56 \\
\hline $\begin{array}{l}\text { There was no economic justification for the private sector to } \\
\text { enter the sport }\end{array}$ & & 57 \\
\hline $\begin{array}{l}\text { High economic risk for investor entry into sports places } \\
\text { privatization }\end{array}$ & & 58 \\
\hline $\begin{array}{l}\text { Entering sports brokers instead of economic entities into } \\
\text { investing in sports places privatization }\end{array}$ & & 59 \\
\hline $\begin{array}{l}\text { Small capacity of the country to enter the private sector of } \\
\text { sports facilities }\end{array}$ & & 60 \\
\hline Increasing the economic power of the government & & 61 \\
\hline Recession in society & & 62 \\
\hline $\begin{array}{l}\text { Low economic profitability of sports facilities for the private } \\
\text { sector of sports facilities }\end{array}$ & & 63 \\
\hline People's attitude towards sports & $\begin{array}{l}\text { Social and } \\
\text { Cultural }\end{array}$ & 64 \\
\hline $\begin{array}{l}\text { People's pessimistic attitude towards sports places } \\
\text { privatization and problems with managing and securing } \\
\text { private clubs }\end{array}$ & & 65 \\
\hline $\begin{array}{l}\text { Changing managers' attitude towards sports places } \\
\text { privatization }\end{array}$ & & 66 \\
\hline Create popular demand for sports development & & 67 \\
\hline $\begin{array}{l}\text { Not prioritizing sports and getting out of the household } \\
\text { requires }\end{array}$ & & 68 \\
\hline $\begin{array}{l}\text { Eliminate the monetization attitude and engage more with the } \\
\text { private sector }\end{array}$ & & 69 \\
\hline $\begin{array}{l}\text { The monetization approach of the national media rather than } \\
\text { the developmental view of sport }\end{array}$ & & 70 \\
\hline $\begin{array}{l}\text { Development of sport by municipalities and education } \\
\text { organization }\end{array}$ & & 71 \\
\hline
\end{tabular}




\begin{tabular}{|l|l|l|l|}
\hline Poor people's living and financial conditions & & & 72 \\
\hline Religious and cultural conditions for women to enter sports & & & 73 \\
\hline Idealistic expectations without executive guarantees & & 74 \\
\hline The role of IRIB organization in creating sports culture & News coverage & & 75 \\
\hline $\begin{array}{l}\text { Proper propaganda and culture of the press and IRIB } \\
\text { organization in relation to sports places privatization }\end{array}$ & & 76 \\
\hline $\begin{array}{l}\text { The Positive Role of Social Media and Media in Sport } \\
\text { Development }\end{array}$ & & & 77 \\
\hline
\end{tabular}

7 categories and 77 concepts are placed in contextual conditions or base; which the contextual or base categories includes internal resources, political, manpower resources, laws and prescriptions, economic, social and cultural status, news coverage. These are factors that provide the platform for the development of the sports places privatization program.

Table 3. Pivotal coding results for level 2 of strategies.

\begin{tabular}{|l|l|l|l|}
\hline Concepts & $\begin{array}{l}\text { Sub-structures } \\
\text { (categories) }\end{array}$ & $\begin{array}{l}\text { Main } \\
\text { structure }\end{array}$ & Row \\
\hline Training a specialist manpower to enter the private sector & Managerial & Strategies & 1 \\
\hline $\begin{array}{l}\text { The desire of top managers and government officials to } \\
\text { implement sports places privatization }\end{array}$ & & & 2 \\
\hline $\begin{array}{l}\text { Applying and bringing in educated physical education staff } \\
\text { and university professors into the private sector }\end{array}$ & & 3 \\
\hline Training manpower to enter the private sector & & & 4 \\
\hline Using the country's internal potential and attracting investors & & 5 \\
\hline $\begin{array}{l}\text { Establish specialized working groups and committees for } \\
\text { needs assessment and legislation at the down-stream levels }\end{array}$ & & 6 \\
\hline $\begin{array}{l}\text { Determine goals and tasks for each of the organizations } \\
\text { involved in the privatization of sports facilities }\end{array}$ & & & 7 \\
\hline Step-by-step private placement in sports with easy conditions & Legal & 8 \\
\hline $\begin{array}{l}\text { Facilitate the implementation of sports places privatization for } \\
\text { the private sector }\end{array}$ & & 9 \\
\hline $\begin{array}{l}\text { Government oversight on proper implementation of sports } \\
\text { places privatization }\end{array}$ & & & 10 \\
\hline $\begin{array}{l}\text { Reform governmental laws in the area of sports places } \\
\text { privatization }\end{array}$ & & & 11 \\
\hline Create tax exemptions for sports places privatization & & & 12 \\
\hline $\begin{array}{l}\text { Financial incentives to attract the private sector to sports } \\
\text { venues }\end{array}$ & & & 13 \\
\hline Clarify the rules & & 14 \\
\hline $\begin{array}{l}\text { Clarify and modification of sports places privatization laws at } \\
\text { a lower level }\end{array}$ & & 15 \\
\hline $\begin{array}{l}\text { Reducing government supervision and intervention leverage } \\
\text { on the private sector }\end{array}$ & & 16 \\
\hline Localization of laws in different areas & & 17 \\
\hline Review the rules in the executive section & & \\
\hline
\end{tabular}




\begin{tabular}{|c|c|c|}
\hline Using the experiences of successful countries & $\begin{array}{l}\text { Privatization } \\
\text { structure }\end{array}$ & 19 \\
\hline $\begin{array}{l}\text { Selection of sports places privatization in accordance with the } \\
\text { political and economic conditions of society }\end{array}$ & & 20 \\
\hline Introducing the private sector to the people & & 21 \\
\hline Reforming the sport structure of the country & & 22 \\
\hline Reaching a unified understanding of the privatization issue & & 23 \\
\hline Ruling competitive thinking and breaking monopoly & & 24 \\
\hline Strengthening physical culture through a tendency to exercise & $\begin{array}{l}\text { Social and } \\
\text { Cultural }\end{array}$ & 25 \\
\hline Attention to the philosophy of sport and culture & & 26 \\
\hline $\begin{array}{l}\text { Introducing private sector managers to the challenges and } \\
\text { opportunities of the sports places privatization sector }\end{array}$ & & 27 \\
\hline Promote management culture in politicians & & 28 \\
\hline Attracting benevolent athletes & & 29 \\
\hline Advertising in order to attract investors in sport places & & 30 \\
\hline
\end{tabular}

Four categories and 30 concepts have been formulated as effective strategies, namely managerial and legal proceedings, privatization, cultural, and social structures that are effective on pivotal phenomenon (development of sports places privatization program).

Table 4. Pivotal coding results of level 2 of outcomes.

\begin{tabular}{|l|l|l|l|}
\hline Concepts & $\begin{array}{l}\text { Sub-structure } \\
\text { (categories) }\end{array}$ & $\begin{array}{l}\text { Main } \\
\text { structure }\end{array}$ & Row \\
\hline $\begin{array}{l}\text { Reduce government spending by expanding sports places } \\
\text { privatization }\end{array}$ & $\begin{array}{l}\text { Economic } \\
\text { development }\end{array}$ & Outcomes & 1 \\
\hline $\begin{array}{l}\text { Reduce government ownership and cost by implementing } \\
\text { sports places privatization }\end{array}$ & & 2 \\
\hline $\begin{array}{l}\text { Private and public sector work together and more } \\
\text { synergies }\end{array}$ & & & 3 \\
\hline Achieving political-economic development of the country & & & 4 \\
\hline Achieving independence in private practice & & 5 \\
\hline Specializing in sports places privatization & $\begin{array}{l}\text { Manpower } \\
\text { development }\end{array}$ & 6 \\
\hline $\begin{array}{l}\text { Increase productivity by implementing sports places } \\
\text { privatization }\end{array}$ & & & 7 \\
\hline $\begin{array}{l}\text { Make the government agile by implementing sports places } \\
\text { privatization }\end{array}$ & & & 8 \\
\hline $\begin{array}{l}\text { Training of manpower and capable managers through } \\
\text { privatization }\end{array}$ & & & 9 \\
\hline $\begin{array}{l}\text { Increase supervision on manpower by implementing } \\
\text { sports places privatization }\end{array}$ & & & 10 \\
\hline $\begin{array}{l}\text { Recruitment and employment manpower by implementing } \\
\text { sports places privatization }\end{array}$ & & & 11 \\
\hline $\begin{array}{l}\text { Success in sports in all areas of the public, from } \\
\text { championship to professional }\end{array}$ & Sport Development & & 12 \\
\hline
\end{tabular}




\begin{tabular}{|l|l|l|l|}
\hline $\begin{array}{l}\text { Developing sports by implementing sports places } \\
\text { privatization }\end{array}$ & & 13 \\
\hline Pay attention to public sport and the development of sport & & & 14 \\
\hline Earning a higher quality of life and receiving services & Social Development & & 15 \\
\hline $\begin{array}{l}\text { Public ownership and stakeholder participation and } \\
\text { greater participation in sport }\end{array}$ & & 16 \\
\hline $\begin{array}{l}\text { Community satisfaction from the interests of sports places } \\
\text { privatization }\end{array}$ & & & 17 \\
\hline A culture of investing and costing for sports & & & 18 \\
\hline $\begin{array}{l}\text { Earn social and cultural benefits by implementing sports } \\
\text { places privatization }\end{array}$ & & 19 \\
\hline
\end{tabular}

4 categories and 19 concepts are placed in the resulted outcomes that are: implications for economic development, manpower resource development, sport development, social development that are pivotal to the phenomenon (development of sports places privatization).

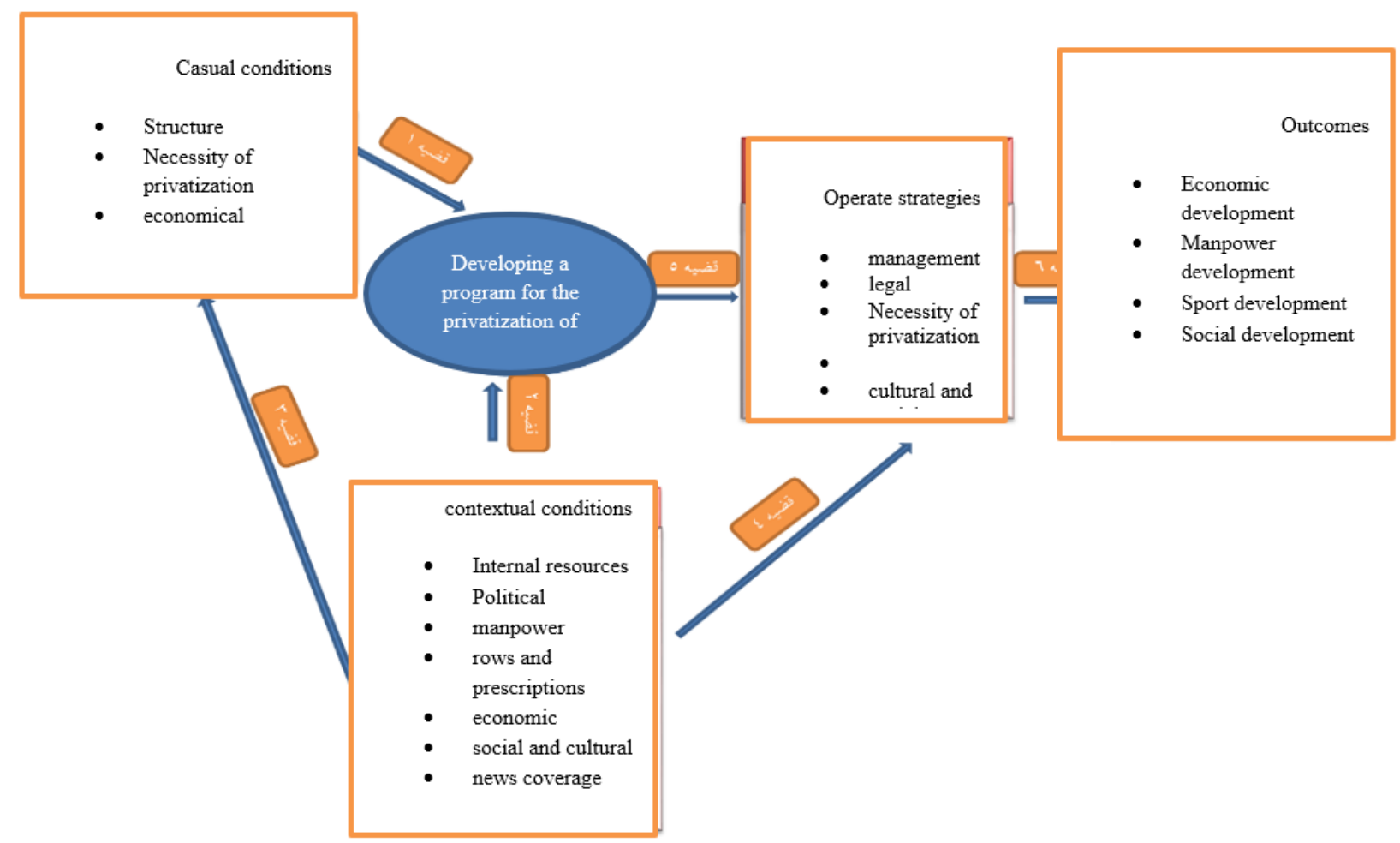

Figure 1. Fiat statements or research theorems.

As can be seen in Figure 1, the development of the sports places privatization program faces various causal conditions. Although these barriers directly affect sports places privatization (Theorem 1 and 2), in addition to, it seems that contextual conditions to be dual importance due to affecting causal conditions (Theorem 3). In other words, the development of the sports places privatization program first of all needs to improve the contextual conditions thereby diminishing the role of causal conditions that have been identified in fields similar to the contextual conditions. Improving these contextual conditions requires the use of managerial, legal, privatization, cultural and social structures that are consistent with these contextual conditions 
(Theories 4 and 5) and can help improve the existing situation. Ultimately, the application of these strategies to the development of the sports places privatization program can have implications for economic development, manpower resource development, sport development, social development (Theorem 6).

\section{DISCUSSION AND CONCLUSION}

3 categories and 10 concepts fall template the causal conditions that are the structural factors, the need for privatization, and the economic factors that influence the pivotal phenomenon. In the investigation of conducted research, in a research by Mischler et al. (2009) on private fitness clubs in France it found that: People have referred to fitness centres for health mentation, but the facilities do not meet the needs. Many private fitness centres are closed due to financial problems. Managers of private fitness centres are more affected by financial motivations. As is clear from the results of the data in interviews with elites and also in similar researches; structural factors, the necessity of privatization, and economic factors are major contributors to the development of the sports places privatization program, which Ahsa and elites has emphasized this as the causal factors. Large sport sections have exchanged to a complex operation that provide large-scale infrastructure with diverse recreational facilities. All of this works are costly, and this begs the question of how to properly provide and manage this cost of these places. A number of development steps and operational stages must be followed for each sport project. In addition, each step has a number of decision options. The purpose of the privatization policy is to improve the efficiency of activities, allocate resources, and expand popular participation in various productive and commercial sectors, including development plan policies. Strategic goals of privatization can include economic, social, and cultural development of the country, the necessity of outsource macroeconomic policy, gain economic benefits in the private sector, shrinking the government, reduce government budgets, reduce government responsibility, gain new resources to enter the governmental sector, proper using of limited government resources and etc. However, considering the high potential of the private sector in sports can solve many problems. Other research on privatization in sport has emphasized the importance of such cases, such as researches by Ackerman (1994) and Mischler et al. (2009), which emphasize the above findings.

The 7 categories and 80 concepts are placed in the base or contextual conditions that include internal, political and manpower resources, laws and prescriptions, economic, social, and cultural status and news coverage; are some factors that provide the base for sports places privatization. Den Hark et al. (2015) in a study entitled governmental and private partnerships in sport infrastructure and complexity interference in Belgium stated that non-concurrence is obvious between the complex approach of government and relatively simple infrastructures that are expanding. The arguments therefore suggest that a better understanding of future plans is needed. As data results of interviews with elites and similar research indicate, factors related to internal, political, manpower resources, laws and prescriptions, economic, social, and cultural status and news coverage are factors that provide the base for the development of the sports places privatization program. The history of privatization and its role in sustaining governments has led economists to interpret privatization as a response from the state to the government for greater prosperity.

generally, privatization enhances market power and credibility against government decisions. actually, privatization is determined due to the goals of each country, meaning that in industrialized and developed countries the way of privatization differs from that of developing countries, because people's expectations of privatization are quite different (Mehrabanfar, 2016). Plans for the development of sports places privatization have not been specifically stated. This confusion in planning and the lack of a long-term plan to implement it have created problems for both the private and governmental sectors. Government remains keen to retain ownership in various sectors of the country's sport the government's unwillingness to lose power is one of 
the factors hampering the privatization process that examples of this can be seen in the additional restrictive laws and stringent laws of various government agencies in the administration of private sporting places. Privatization has not reached the level it should be considered, to date.

4 categories and 30 concepts have been put into effective strategies; strategic sector categories include managerial proceedings, legal, privatization structure, cultural and social structures that are affect pivotal phenomenon (development of sports places privatization program). As elites have pointed out in interviews, sovereignty, socio-cultural, media, managerial, and institutional measures are essential strategies that influence the development of the sports places privatization program. these cases are confirmed by reviewing previous research and comparing its results with elites' opinion.

Pinto (2005) stated in state and local government congresses about the mechanisms of investment and participation that beyond governmental financial resources, governments require joint venture with the private sector and some incentives to support them seem necessary. State's reliance on governmental budget and state aid, sovereignty of government over non-competitive approach to sport, inability to utilize existing capacities in sports, problems for federations with international sports institutions, and deprivation arising from government interference in sports affairs are some problems of governmental sports sector (Governmental Organization of the Islamic Republic of Iran, 2005; quoted by Amiri, 2013) that the government can take a step forward in the development of sport privatization, not by interference and tenure, but by the regulatory role and removal of existing barriers and problems. Investing in the private sector in Iran poses a high economic risk. The low presence of domestic and foreign investors in the sports sector and in the sports privatization sector has diminished this area. The results of researches by Mehrabanfar (2016) and Pour Ahmadi et al (2018) are in line with the present study. To this purpose, the government should alleviate many of the concerns in the private sector contract and investment contract and facilitate the implementation of privatization laws and regulations. If the conditions are provided for the private sector to participate in the sport, considering the appropriate internal potentials, we can witness the proper use of these capacities in the country. Unless the government has a serious determination to implement privatization, all plans and policies in this regard will fail.

The 4 categories and 19 concepts are placed into outcome results framework, which are economic development, manpower resource development, sport development, social development that are affected pivotal phenomenon (sports places privatization). The results of a review by Chengdu Institute of Physical Education (2007) showed that sports places privatization guarantees the speed and quality of structure operations. Sports places privatization raises the level of standard and technology of sports places. The government is active in fund-raising and participate of private sector in the construction of sports facilities. Privatization improves management and practical oversight of sports places. The results of research by Chengdo (2007), T. Samni et al. (2010), Ghorbani Jolodar, and Forghani Ozroudi (2015) were in line with the present study.

In many developing countries, state-owned corporations are used as government tools to achieve optimal resource allocation and economic efficiency but the economic inefficiency, poor allocation of resources, the large loss and imposition on the state budget, become apparent with passing the time and by completing the activities of these companies. But the economic inefficiency, poor allocation of resources, the large loss and imposition on the state budget, become apparent with passing the time and by more complexity the activities of these companies. As a result, widespread moves have been made to transfer and cession the governmental companies to the non-governmental and private sectors. In other words, by privatization, governments seek to use all powers to advance and seek to facilitate the link between society and politics. 
By the development of privatization, the value and cost for sports has become a culture and will be effective steps in the development of sport community. Sport developed influenced by the privatization process, resulting in success in sports in various fields (public to championship and professional). Determining the goals and tasks for each of the organizations involved in the privatization of sport and paying attention to public sport and the development of sport by the municipalities and the training organization is effective in accelerating this.

Finally, structural factors are one of the causes of the development of the sports places privatization program authorities and policy makers are suggested to considering the advantage of long-term benefits of sports places privatization and added-value to society and the necessity of reduce government responsibility by providing financial incentives such as proper conditional facilities, facilitating legal licensing for attraction the private sector to sport cause involvement of privatization process in sports. Given the wide scope of the sports industry in the country and the importance of internal resources in achieving the goals of the sports places privatization plan, it is suggested that the government provide private sector real estate pricing facilities to the private sector, assimilation the rates of use of public places compared to the private sector, the government is taking a step forward in pursuing the goals of developing the sports places privatization program and putting more effort into creating a private investment market.

\section{REFERENCES}

Amiri, Mojtaba-Nayyeri, Shahrzad; Saffari, Marjan; Delbari Raghab, Fatemeh. (2013). Explaining and Prioritizing the Obstacles to Privatization and Private Sector Participation in Sport Development, Sport Management, Vol 5, Number 4, p. 83 - 106.

Chengdu Institute of Physical Education (2007). Swot Analysis of Pushing on PFI Financing Pattern in Public Sport Facilities and Countermeasure. Journal of Chengdu sport university. p 33.

Den Hurk, Martijnvan\& Verhoest, Koen (2015). The Governance of Public-Private Partnerships in Sports Infrastructure: Interfering Complexities in Belgium. International Journal of Project Management, Volume 33, Issue 1, January 2015, Pages 201-211. https://doi.org/10.1016/i.jproman.2014.05.005

Eissens,W. J. (1994). Privatisation of Sports Facilities in the Netherlands. European Journal for Sport.1, 4-12.

Ghanbari Firouzabadi, Ali Reza. (2009). The Status of Sports Places Privatization in Iran from the Perspective of Owner, Manager, and User and Comparing it with Selected Countries - Model Submission, Doctoral Dissertation; Faculty of Physical Education and Sport Sciences Tehran University of Teacher Education.

Ghorbani Jolodar, Tahereh; Forghani Ozroudi, Mohammad Bagher; (2015). The Relationship between Privatization and Efficiency of Sports Halls from the Perspectives of Managers and Heads of Sports Boards. Sport Management Studies. Article 6, Vol 7, Number 33, p. 83-98.

Islamic Republic of Iran physical education organization (National Center for Sport Management and Development of the country). (2005), "Detailed Studies in Management Development and Planning", First Edition, Sib-e- Sabz Publications.

Lindholm, Anna, Liisa. (2005). Public Facilities Management Services In Local Government. Helsinki University of Technology, Department of Surveying, Institute of Real Estate Studies.

Mehraban far, Ehsan (2016), Pathology of Government Policy Making in the Field of Privatization According to Data-based Theory, Majles va Rahbord, Vol 23, Number 86; P. 329-350.

Mischler, S, Bauger, P, Pichot, L, Wipf, L, (2009).Private Fitness Centers in France: from Organisational and Market Characteristics to Micromentalities of the Managers. Journal of Sport Management and Marketing.5, 4.426-447. https://doi.org/10.1504//JSMM.2009.023370 
Mosalla Nejad, Mohammad; Tabrizi Ghahraman, Koroush \& Sharifian, Ismail. (2014). Barriers to Privatization of Sport Facilities of Iranian Public Universities, Research in Academic Sport, Vol 2, Number 6, p. 87 - 112.

Nasseh, M (2013). Evaluation of Privatization in Sports with the Approach of Assessing the Strengths and Weaknesses, European Journal of Experimental Biology, 3(1):631-636.

Parker, D. (2013). "The Official History of Privatization", Vol. II: Popular Capitalism, 1987-97, Routledge, Whitehall Histories, and Government Official History. https://doi.org/10.4324/9780203122143

Pour Ahmadi Moein, Mokhtarian Pour Majid, Hassangoli Puria, souri Tahmoures (2018). The Pathology of Implementation of Privatization Policies in Iran. Issue: Public Administration (Management Knowledge); Issue: Autumn 2018, Vol 10, Number 3; p. 333- 356.

Rahimi Boroujerdi, Al. (2006). Privatization. Tehran: University of Tehran, Institute of Publishing and Printing.

Salimi, M, Soltanhosseini, M, Padash,D \& Khalili, E. (2012). Prioritization of the Factors Effecting Privatization in Sport Clubs: with AHP \& TOPSIS Methods - Emphasis in Football. International Journal of Academic Research in Business \& Social; Feb2012, Vol. 2 Issue 2, p102.

Taheri, Shahnam (2005). Economic Development and Planning. Tehran: Hastan Publication.

Tsameny, M, Onumah, J. Tetteh-Kumah, E. (2010). "Post-Privatization Performance and Organization Changes: Case Study from Ghana". Critical Perspectives on Accounting, 21, p. 428-442. https://doi.org/10.1016/j.cpa.2008.01.002

Welch, Dick, and Fremund, Elivier. (2010). Step-by-Step Privatization of Methods and Examples. Privatization Organization; Studies in Management and Planning, Tehran: Etrat printing, p 93.

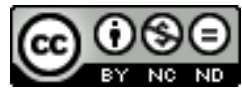

This work is licensed under a Attribution-NonCommercial-NoDerivatives 4.0 International (CC BY-NC-ND 4.0). 